duties than of his rights. The outstanding statement in the book for me came in the first page of the introduction 'almost all the time the interests of the health care provider and the patient are the same'. Doctors have always subscribed to this sentiment but how refreshing to see it acknowledged by those whose interests lie in health law rather than in patient care.

That the gulf between lawyer and doctor is by no means bridged is however made very apparent when one reads that 'understanding of the law can be as important to the proper care of patients as an understanding of emergency medical procedures or proper drug dosages'.

The scope of the book is indeed very much wider than its title might have one believe. Much basic information is given and a number of misconceptions corrected. As an example of the former the reader learns that the cost of malpractice insurance premiums rose from 250 million dollars in 1970 to 2 billion dollars in 1980 .

That the American doctor runs enormous risks in assisting at roadside accidents has for years been firmly believed by many in the UK. The authors firmly nail that one by telling us that there has been 'not one reported case in which a health care professional in this country has had to pay any money damages to anyone suing him for stopping and rendering aid and allegedly aggravating the patient's condition ...'

The book is written in the form of question and answer and this format permits the authors to cover a great deal of medical law in a manner readable to doctor and nurse. The profession's duty in respect of the disabled doctor is considered and the relationship between doctor and hospital administrator is explored.

Nursing and the law is investigated in some detail as are the respective liabilities of doctors, nurses and other health care professionals. The role of the social worker in the US is stated to be still ill-defined.

The chapters on consent, human experimentation and research and privacy and confidentiality emphasise to me the great similarities which exist between UK and US law. The chapter on the Union movement in health care in institutions is perhaps somewhat out of place in a book of this nature, but the one on malpractice litigation is a mine of information.

The appendices, which include a glossary of legal terms and an excellent index, conclude a book produced at a price which should ensure its purchase by all who have any interest in medical law in the United States.

J LEAHY TAYLOR Secretary Medical Protection Society London

\section{Light in Darkness: Disabled Lives?}

Papers on some contemporary medical problems, collected by the Medical Committee, Order of Christian Unity, London

Oxford, Unity Press, Mowbray and Co Ltd

£2.25

Here are 12 papers, mostly short and mostly new, though some are re-printed from elsewhere. There are three sections: (i) A Positive Approach to Life; (ii) Potential in Disability, and (iii) Dignity in Dying. The British authors are well known and $I$ assume that is true of those from the USA. The sections are preceded by an introduction on 'Some Dilemmas of Modern Medicine' by Sir John Peel. The general theme is the prevention and alleviation of disabilities, coping with disabilities and, in the end, coping with terminal illness. This theme was particularly appropriate in the International Year of the Disabled when the book was published. The attitudes of medical folk, the social services, parents and relatives are discussed, in addition to that of the sufferer. The aim of the book is to present a strong case against dealing with disabilities by any form of euthanasia or (with very few exceptions) by abortion. A Christian basis is advanced for this stance. Three of the contributors: Pat Seed, Gordon Scorer and Leonard Cheshire produce Christian meditations to support it. But how one moves from a basic stance to these particular ethical decisions is not discussed; nor why some Christians have arrived at different ones. The chapter on 'Why Abortion?' by a lecturer in logic, himself a paraplegic, does not resolve it. In his introduction Sir John says 'One of the difficulties that doctors have in the whole field of ethics is that morality is about absolutes . . . the value of human life is infinite. Doctors on the other hand are all the time having to make decisions based on the relative ...' Moral theory, however, is about both; and the phrase about human life by itself does not resolve the issues of medical ethics discussed in this book. A section of the report On Dying Well, produced by the Board of Social Responsibility of the Church of England in 1974 is reproduced and reads well after eight years. The publishers claim that the book is 'refreshingly new'. It is not. But its warnings and its positive points are important, if not as decisive as it thinks.

PROFESSOR RONALD PRESTON

Faculty of Theology University of Manchester

The Politics of Contraception was first $\mathbb{D}$ published in 1979. This is a welcome $\vec{\Rightarrow}$ re-issue with a new preface and an added article Birth Control in the Year $200 I$ although this does little more than summarise the contents of the original book.

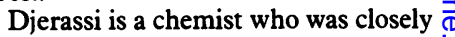
involved in the synthesis of the first oral $\frac{0}{7}$ contraceptive (the book includes an account of the chemical development of $\delta$ the Pill) but his interest in contraception is not only that of a scientist. He is concerned about world population growth and sees the control of fertility as the most urgent social issue of the next 20 years. $\mathrm{He}$ is also an industrialist $N$ who is very frank about the profit ${ }^{\circ}$ motive behind much scientific research $N$ in the United States. The result is a N fascinating book which considers the factors that affect the development, availability and use of contraceptive methods in the present and discusses $\stackrel{D}{\oplus}$ how the interaction between science, $\stackrel{?}{+}$ industry and public policy may affect $\underline{T}$ future developments.

Dierassi touches on a number of ethi- $\frac{\mathbb{D}}{\mathbb{Q}}$ cal issues but his concern with conse- $\mathbb{\mathbb { D }}$ quences rather than with rights limits 
the scope and value of some of these discussions. However, there are two issues which are explored in some detail. Under the heading 'The Public's Right to Know' he considers the implications of the 1972 Nelson hearings Senate hearings which explored the extent of public dissemination of information about the risks of the Pill - and the media coverage of these hearings. He concludes that it is reasonable to link the public's right to know to the freedom of the press as long as this 'does not license the media to disseminate important information - especially that of a complex technical nature - irresponsibly and with little appreciation of the consequences'. Unfortunately he makes no suggestions about how such control of the media could be achieved!

Djerassi suggests that it was as a direct result of the Nelson hearings that all Pill packs (in Britain as well as in the US) now contain inserts specifying the Pill's side-effects. While applauding the principle of package inserts for all drugs, he rightly questions 'whether the legalistic manner in which the negative side-effects of the Pill are described in order to protect the manufacturer against possible liability is a helpful way to convey important information'.

The other issue runs right through the book - that is, how to balance the need to produce new contraceptive methods as rapidly as possible against the demand for the utmost safety. In Djerassi's view, the greater power of the Food and Drugs Administration (FDA), the development of consumer groups and an increasing fear of litigation have led to a shift in this balance, particularly in the US, such that the emphasis on safety has not only slowed down the development of new contraceptives but has made it increasingly unlikely that industries will consider even investing in any new development with so little prospect of profit. Clearly there is a need for government-funded (including internationally-based) research and fortunately some other countries are more willing to consider this than the US. According to Djerassi up till I 979 the US had still not contributed funds to the World Health Organisation's birth control programme.

Although Dierassi makes suggestions to encourage further research and innovation in the US, he does not claim that he can solve the basic dilemma of 'how to balance innovation with risk?'. Yet his own priority is clear and he states this as the reason for writing the book. 'In birth control, time is the most expen- sive commodity' and we do not have an unlimited amount of time.

DR JUDY BURY Brook Advisory Centre Edinburgh

\section{Social Work with Undervalued Groups}

\author{
Ruth Wilkes \\ London, Tavistock Publications \\ £8.50 (paperback $£_{3.75)}$
}

Ruth Wilkes, in Social Work with Undervalued Groups, has made a stimulating and challenging contribution to the debate about values in social work, a subject which she believes is all too often neglected in favour of discussions about aims and methods.

Her thesis is that by making sociology and psychology rather than moral philosophy the underpinning of social work training we have shifted social work from its central value of concern for the individual, whoever he or she may be, towards a profession which manages and controls people's lives and fits them into the socially defined values of our time.

She examines two different justifications in moral philosophy for interfering in people's lives - notions of positive and negative freedom. Positive freedom is concerned with the realisation of one's 'true' self and justifies interference in the lives of others for their own good and for the good of society. Negative freedom is freedom from interference or freedom to do whatever you choose: interference in the lives of others is only justified in order to prevent harm to others or for self-protection.

Social work has unquestioningly adopted a base of positive freedom aiming as it does to do good and to perfect Man and society. Ruth Wilkes believes that social work should be based rather on a notion of negative freedom, that it should aim to avoid harm. She believes that the social worker should strive less to perfect methods and techniques which go to make the worker a more effective and purposeful manager and controller of people's lives, and more to understand the pain and suffering of each individual, to be receptive to his or her particular experience and to respond creatively with love, compassion and openmindedness.

We are asked to shift from the current analytic, empiricist approach to a metaf physical one. This approach goes beyond what can be explained by sociâ conditioning or socially created valueg and norms to seeing each human being as unique and infinitely resourceful io his search for harmony both withif himself and with the natural order.

I can recommend Ruth Wilkes brave and personal challenge to socia work to all those involved in it, but? steeped in a positivist way of thinking as most of us are, it is not an easy book to read. It takes a leap of faith to embrace the metaphysical approach.

The author seems to suggest that social work is on the wrong track. How ever, I believe that it is possible to develop social work in Social Services Departments (which do undoubtedlo encourage a managerial approach), anco at the same time develop more intuitive and creative forms of work in these and other agencies. With the development' of specialties there is more and more interest in the old, the mentally an physically handicapped, and the sick and dying, all of whom the autho believes are undervalued in current practice.

The book is a timely reminder of limited power in the face of the sadiress of others, of the need to see end strengths in others, and of the need.rof to believe that in social work we can ō should control other people's lives.

CAROLINE POLMEAR Lecturer in Social Wor Bedford College London Universit

\section{Rights and Responsibilities in Modern Medicine}

\author{
Ed Marc D Basson \\ New York, Allan R Liss, Inc \\ $£_{15.00}$ DM66.00
}

This book is the second volume in series on ethics, humanism and medicine, and it consists of the proceed ings of the I979-1980 conferences $Q B$ those topics held at the University of Michigan, Ann Arbor. The participant at the conferences came from a variety of disciplines, such as various branches of medicine, law, theology, philosoph and veterinary medicine, and it is a trie bute to them and their editor that theis disciplines provide backgrounds ratheg 